\section{Duodenal ulcers which do not heal rapidly}

Between a quarter and a third of duodenal ulcers in patients in Britain heal during one month's treatment with placebo. ${ }^{1}$ The rate of healing is increased to between just under two thirds and four fifths after treatment for one month with many drugs. ${ }^{1}$ Such rates are far from satisfactory, since ulcers which have not completely healed either remain a source of symptoms or soon become clinically active again. ${ }^{2}$ In practice, either healing has to be confirmed endoscopically after treatment for four weeks or, if that facility is not available, all patients must be treated for eight weeks, since many reports have shown that two months' treatment with, for example, cimetidine ${ }^{1}$ or ranitidine ${ }^{3}$ heals more than $90 \%$ of duodenal ulcers.

That still leaves a few patients (less than $10 \%$ ) with active duodenal ulcers after treatment for two months. Sometimes the therapeutic "resistance" is seen during the first course of treatment, but in other patients previous courses of treatment may have been normally successful. Reasons that have been proposed for the resistance to healing include the size and shape of the ulcers ${ }^{4} ;$; chronicity ${ }^{6}$; duodenal scarring or stenosis $^{6}$; severity of duodenitis ${ }^{7}$; abnormal drug pharmacokinetics ${ }^{8}$; the extent of the gastric secretory response to stimulants $^{6}$; failure of the drug to control acid secretion ${ }^{9}$; smoking ${ }^{610^{11}}$; and the use of analgesics. ${ }^{4}$ The role of all of these factors has been supported and refuted in countless studies and the one certain conclusion is that the cause of "refractory" duodenal ulceration has not yet been defined.

These refractory ulcers often give rise to symptoms, so what therapeutic options are available for a patient whose ulcer remains unhealed after two months of treatment? Firstly, the same treatment may be continued and some ulcers will heal in due course. ${ }^{7} \mathrm{Next}$, the dosage of the original drug may be increased, because it seems (not surprisingly) that some patients require larger than average doses. This type of approach heals not only many duodenal ulcers ${ }^{7}$ but also the ulcers of patients with gastrinomas, who may need up to 10 times the standard dose of cimetidine. ${ }^{12}$ The third therapeutic option is to change the antiulcer drug: both ranitidine and colloidal bismuth subcitrate have been reported to heal ulcers resistant to cimetidine. ${ }^{313} 14$

Unfortunately, many of the reports of the successful treatment of refractory ulcers are unsatisfactory and cannot be used as general guides to treatment because they have been based on open trials in which patients have acted as their own historical controls. Formal randomised controlled trials, in which half of the patients continue the original treatment, have proved difficult to organise because so few duodenal ulcers remain unhealed after two months of treatment. For example, in our population, about $97 \%$ of the ulcers heal during two months of treatment, so that we need to start with 1000 patients if we are to study two trial groups with 15 patients in each.

Ulcers resistant to drugs may also be treated surgically. No comparisons are available of continued medical treatment and operation. The open studies suggest that resistant ulcers heal normally after operation, ${ }^{15} 16$ although some recent reports have noted-ominously - that after vagotomy without, or with, drainage the ulcers recur in about half of the patients. ${ }^{17}$

What practical advice can be given? The evidence suggests that when attempting to heal duodenal ulcers it is safest to treat for two months unless earlier endoscopic re-examination confirms healing of the ulcer. If the ulcer has not healed the dose of cimetidine or ranitidine should be doubled or a different drug should be tried. Operative treatment should be avoided, if possible, because the patient will probably require major gastric surgery (such as vagotomy plus antrectomy) with its attendant mortality and morbidity. So many new antiulcer drugs are being studied at present that another one can always be tried in the hope that it will prove suitable; the persistently refractory ulcer is so rare that no generalisations apply.

\section{K G WORMSLEY}

Consultant Physician,

Department of Therapeutics,

University of Dundee,

Ninewells Hospital,

Dundee DD1 9SY

1 Wormsley KG. Short-term treatment of duodenal ulceration. In: Baron JH, ed. Cimetidine in the '80s. Edinburgh: Churchill Livingstone, 1981:3-8.

Paoluzi P, Ricotta G, Ripoli F, Proietti F, Carratu R, Torsoli A. Incomplete and completely healed duodenal ulcers outcome in maintenance treatment: a double blind controlled study. Gastroenterology 1982;82:1146.

Boyd EJS, Wilson JA, Wormsley KG. Review of ulcer treatment: role of ranitidine. In: Hirschowit BI, Sperry JG, eds. Receptors and the upper GI tract. New York: Advanced Therapeutic Communications Inc, 1983:292-303.

Lam SK, Koo J. Accurate prediction of duodenal-ulcer healing rate by discriminant analysis Gastroenterology 1983;85:403-12.

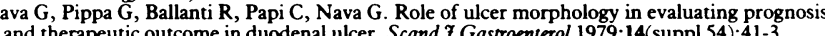
and therapeutic outcome in duodenal ulcer. Scand f Gastroenterol 1979;14(suppl 54):41-3. low-dose antacid treatment. Gut 1981;22:97-102.

Bardhan KD. Refractory duodenal ulcer. Gut 1984;25:711-7.

8 Somogyi A, Gugler R. Clinical pharmacokinetics of cimetidine. Clin Pharmacokinet 1983;8:463-

Gledhill T, Hunt RH. Studies of intragastric acidity and nocturnal acid secretion in cimetidine nonresponders. Gastroenterology 1982;82:1068.

10 Gugler R, Rohner HG, Kratochvil P, Brandstätter G, Schmitz H. Effect of smoking on duodenal ulcer healing with cimetidine and oxmetidine. Gut 1982;23:866-71.

11 Korman MG, Hansky J, Merrett AC, Schmidt GT. Ranitidine in duodenal ulcer. Incidence of healing and effect of smoking. Dig Dis Sci 1982;27:712-5.

2 Jensen RT. Basis for failure of cimetidine in patients with Zollinger-Ellison syndrome. Dig Dis Sci 1984;29:363-6.

Brunner $\mathrm{G}$, Losgen $\mathrm{H}, \mathrm{Harke} U$. Ranitidine in the treament of cimetidine-resistant ulcerations of the upper intestinal tract. In: Misiewicz JJ, Wormsley KG, eds. The clinical use of ranitidine.

4 Lam SK, Lee NW, Koo J Hui WM Foundation, 1982:254-6.

dicitrato bismuthate versus high dose cimetidine for duodenal ulcers resistant to standard dose of cimetidine. Gut 1984;25:703-6.

15 Blackett RL, Johnston D. Cimetidine and duodenal ulcer: can surgery cure the failures? Gu 1981;22:A434.

6 Pickard WR, MacKay C. Early results of surgery in patients considered cimetidine failures. $\mathrm{Br} \mathfrak{J}$ Surg 1984;71:67-8.

17 Hansen JH, Knigge U. Failure of proximal gastric vagotomy for duodenal ulcer resistant to cimetidine. Lancet 1984;ii:84-6.

\section{Contraception and the mentally handicapped}

Contraception in the mentally handicapped is not often discussed, and when it is there is usually a charged atmosphere, and half truths and absolute myths are repeated. Little wonder, then, that mentally handicapped people, their parents, and relatives are often made more anxious and less effective in attempting to cope.

The effective reproductive capacity of the feeble minded, with an intelligence quotient below 70 , is very limited, and below 50 it is in practical terms negligible.' Possibly, however, the size of the problem may change with the changing pattern of care of the mentally handicapped; with more emphasis on community care in a better physical environment there may be better opportunities for handicapped people to express their sexual feelings.

A few mildly mentally handicapped people marry, and often they themselves do not seek help about contraception, so that sometimes unwanted pregnancies occur. Neverthe- 